\title{
Detection of Toxoplasma gondii infection in feral wild boars (Sus scrofa) through indirect hemagglutination and PCR
}

\author{
Laila Natasha Santos Brandão ${ }^{1}$ Janaina Marcela Assunção Rosa ${ }^{1}$ Beatris Kramer $^{2}$ \\ Alessandra Tammy Hayakawa Ito de Sousa $^{3}$ Iara Maria Trevisol ${ }^{2}$ Virginia Santiago Silva ${ }^{2}$ \\ Luciano Nakazato $^{3}$ Valéria Dutra ${ }^{3 *}$ iD
}

\footnotetext{
${ }^{1}$ Programa de Pós-graduação em Ciências Veterinárias, Universidade Federal do Mato Grosso (UFMT), Cuiabá, MT, Brasil. ${ }^{2}$ Empresa Brasileira de Pesquisa Agropecuária, Embrapa, Suínos e Aves, Concórdia, SC, Brasil.

${ }^{3}$ Laboratório de Microbiologia Veterinária e Biologia Molecular, Universidade Federal de Mato Grosso (UFMT), 78060-900, Cuiabá, MT, Brasil. E-mail: valeriadutra.dutra@gmail.com. .Corresponding author.
}

ABSTRACT: Wild boars (Sus scrofa) have become an important invasive species in all Brazilian regions. Increase in their population causes damage to rural properties, as they invade and destroy crops. To protect their crops and farm animals, producers hunt wild boars and often consume the product without any sanitary control, becoming exposed to various types of pathogens, including Toxoplasma gondii. Sanitary evaluations of these animals are scarce, especially in relation to the protozoan $T$. gondii. This study aimed to evaluate the occurrence of this pathogen in wild boars in Brazil. We analyzed 122 blood samples from wild boars (blood clots and serum), collected between 2014 and 2016 in five Brazilian states, using polymerase chain reaction (PCR) and indirect hemagglutination (IH) techniques. In total, 33 (27\%) samples were positive by at least one test, 16 (13.1\%) were positive by PCR, 19 (15.6\%) were positive by IH, and only 2 (1.6\%) were positive by both tests. The lack of sanitary management of feral animals increases the incidence of infections, and the consumption of raw or inadequately cooked meat may become a potential source of infection for humans in Brazil.

Key words: Toxoplasmosis, wild boar, zoonosis.

Detecção de infecção por Toxoplasma gondii através da hemaglutinação indireta e PCR em javalis (Sus scrofa) de vida livre

RESUMO: Os javalis (Sus scrofa) tornaram-se uma importante espécie invasora em todas as regiões do Brasil. Com o aumento de sua população causam danos em propriedades rurais, invadindo e destruindo lavouras. Como alternativa para proteger suas culturas e criações, os produtores os caçam e muitas vezes consomem o produto sem qualquer tipo de controle sanitário, expondo esses consumidores a diversos tipos de patógenos, entre eles o Toxoplasma gondii. Avaliações sanitárias destes animais são escassas, principalmente, em relação ao protozoário T. gondii. Este trabalho teve como objetivo avaliar a ocorrência deste patógeno em javalis de vida livre no Brasil. Foram analisadas 122 amostras de sangue de javalis (coágulos sanguíneos e soro), coletadas entre os anos de 2014 a 2016, de cinco estados do Brasil, através da técnica da Reação em Cadeia da Polimerase (PCR) e da técnica de hemaglutinação indireta (HI). No total, 33 (27\%) amostras foram positivas em pelo menos um teste, sendo $16(13,1 \%)$ na PCR e 19 (15,6\%) na IH e apenas 2 (1,6\%) em ambos os testes. A falta de manejo sanitário dos animais ferais aumenta a incidência de possíveis infecções e o consumo da carne crua ou sem cocção adequada pode vir a ser potencial fonte de infecção para humanos.

Palavras-chave: Toxoplasmose, javali, zoonose.

Wild boar (Sus scrofa), and its crosses with domestic pigs (Sus scrofa domesticus), are considered "invasive exotic species" (SIMBERLOFF, 2013), being the second largest threat to global biodiversity (SIMBERLOFF, 2013) because they cause the extinction of native species of fauna and flora (PEDROSA et al., 2015).In Brazil, the occurrence of wild boars has been recorded in 472 municipalities (PEDROSAet al., 2015), demonstrating a high potential for invasion and adaptability (BARRIOSGARCIA \& BALLARI, 2012) and causing great damage to rural properties (PEDROSA et al., 2015).

As a means of population control, many producers hunt wild boars, and their meat is usually consumed in the form of handmade cold meat without proper cooking, disregarding sanitary control protocols. As such, it may represent an important source of infection by several agents, including Toxoplasma gondii (T. gondii) (ROSTAMI et al., 2018).

Toxoplasmosis is currently the most frequently diagnosed zoonosis in humans. It is estimated that approximately one-third of the world's population is infected with $T$. gondii. This infection may be associated with the consumption of contaminated foods, such as raw or improperly cooked meat (ROBERT-GANGNEUX \& DARDÉ, 2012; HARKERet al., 2015).

Due to the increase in the hunting of these animals (MASSEI et al., 2015) and the consumption of their meat, in addition to lack of data about wild 
boars health, wild boars cannot be ruled out as a source of contamination to humans. This study aimed to evaluate the occurrence of antibodies and detect T.gondii in feral boars in Brazil.

Samples were collected in the states of Rio Grande do Sul (28), Santa Catarina (73), Minas Gerais (2), Mato Grosso (7) and São Paulo (12), between 2014 and 2016, totaling 122 samples. Collections were only made by authorized and trained hunters (SISBIO36636-7). Blood was collected in tubes without anticoagulant soon after the capture and slaughter of the animals, and clots and sera were stored under refrigeration $\left(-80^{\circ} \mathrm{C}\right)$ until use.

DNA was extracted from the blood clots using $\mathrm{K} /$ phenol/chloroform proteinase, following the recommendations of SAMBROOK \& RUSSEL (2001). Polymerase chain reaction (PCR) test was performed using oligonucleotides for $T$. gondii: TOXO 1 (5'-GGAACTGCATCCGTTCATGAG-3') and TOXO 2 (5'-TCTTTAAAGCGTTCGTGGTC3'), which amplify a 194bp fragment of the B1 gene specific for $T$. gondii (BURG et al.,1989). The reaction was performed with a ring temperature of $57^{\circ} \mathrm{C}$ for 45 by 30 cycles (MyCycler, Biorad), following the same protocol used by MORGADO et al. (2017). The amplification products were analyzed with ChemiDoc ${ }^{\mathrm{TM}}$ XRS after electrophoresis in $2 \%$ gel agarose stained with $\operatorname{Red}^{\mathrm{TM}}$ Gel $\left(\right.$ Biotium $^{\circledR}$ ). The indirect hemagglutination test $(\mathrm{IH})$ was performed in serum using the TOXO-HAI Kit (Gold Analyses Diagnostic Ltd, MG, Brazil), according to the manufacturer's recommendations; a positive (cut-off) dilution was $\geq 1: 32$.

In total, 33 animals (27\%) were positive by at least one of the techniques. Sixteen (13.1\%) animals were positive by PCR, 19 (15.6\%) were positive by $\mathrm{IH}$, and only $2(1.6 \%)$ were positive by both techniques. The frequency distribution by state is presented in Table 1.

The occurrence of positive samples by PCR (13.1\%) indicates that these animals are likely to have acute infections, and that serologically positive animals $(15.6 \%)$ have chronic infections (ROBERTGANGNEUX \& DARDE, 2012). The sensitivity and specificity values of each technique may vary according to the species and the reference values used, making standardization difficult (KHALIFA K EL-S et al., 1994).

In their literature review, ROSTAMI et al. (2017) reported a low occurrence of positive wild boars in several South American countries, ranging from 3 to $8 \%$. However, in our study, we observed
Table 1 - Distribution of $T$. gondii positive samples in wild boars detected the PCR and $\mathrm{HI}$ techniques during 2014 in 2016 in 5 Brazilian states.

\begin{tabular}{lcc}
\hline STATE & PCR $(\%)$ & HI $(\%)$ \\
\hline Minas Gerais $(\mathrm{n}=2)$ & $0(0)$ & $0(0)$ \\
Mato Grosso $(\mathrm{n}=7)$ & $1(14.3)$ & $0(0)$ \\
Rio Grande do Sul $(\mathrm{n}=28)$ & $3(10.7)$ & $3(10.7)$ \\
Santa Catarina $(\mathrm{n}=73)$ & $8(11)$ & $13(17.8)$ \\
São Paulo $(\mathrm{n}=12)$ & $4(33.3)$ & $3(25)$ \\
Total $(\mathrm{n}=122)$ & $16(13.1)$ & $19(15.6)$ \\
\hline
\end{tabular}

a higher percentage of infected animals (27\%), which may be due to regional variations and the combination of diagnostic techniques used, which were able to detect acute (PCR) and chronic (IH) infections (KHALIFA K EL-S et al., 1994; ROBERTGANGNEUX \& DARDE, 2012).

Another important aspect is the lifestyle of wild boars. In Brazil, there is a lower prevalence (4.5\%) of infection by $T$. gondii in farm animals (4.5\%) (FORNAZARI et al., 2009). However, in southern Brazil, there is a higher prevalence $(14.28 \%)$ of infection in feral animals (SANTOS et al., 2016), indicating that domestic animals (BAI et al., 2017) are less likely to be infected than wild animals (DEKSNE \& KIRJUSINA, 2013; KANG et al., 2013).

Occurrence of infection by $T$. gondii varied between states. Positive animals were observed in all states, except for Minas Gerais. The difference between states may be associated with regional variations in the sources of contamination (BAI et al., 2017), as described by the presence of wild felids that can house the sexual stages of parasite and contaminate soil and water (DUBEY, 1994). In the case of Minas Gerais, the absence of positive animals may be associated with the small sample size from this state $(n=2)$ compared to other states.

Occurrence of $T$. gondii, detected by PCR and $\mathrm{IH}$, in wild boars in Brazil suggests the presence of infection in most of the analyzed states, which is a significant finding for the epidemic process of toxoplasmosis since it characterizes these animals as potential hosts. It is important to note; however, that studies on the detection of $T$. gondii in wild boars are still scarce. The consumption of improperly cooked meat from these animals, when hunted, is a potential source of infection for humans, or even domestic animals that eventually consume this meat. 


\section{BIOETHICS}

AND

BIOSECURITY

\section{COMMITTEE APROVAL}

We, the authors of the article entitled "Detection of infection by Toxoplasma gondii through indirect hemagglutination and PCR in feral wild boar (Sus scrofa)", declare, for the intended purposes; that although, the project with the original data was not submitted for evaluation of the Ethics Committee of the Universidade Federal do Mato Grosso, we are aware of the content of the guidelines of the National Council for Control of Animal Experimentation - CONCEA <http://www.mct.gov.br/index.php/ content/view/310553.html $>$ for studies with animals. Thus, the authors assume full responsibility for the data presented and are available for possible questioning.

\section{DECLARATION OF CONFLICTING INTERESTS}

The authors declare no conflict of interest. The founding sponsors had no role in the design of the study; in the collection, analyses, or interpretation of data; in the writing of the manuscript, and in the decision to publish the results.

\section{AUTHORS' CONTRIBUTIONS}

The authors contributed equally to the manuscript.

\section{REFERENCES}

BAI, M. et al. Toxoplasma gondii Infection in Farmed wild boars (Sus scrofa) in three cCities of northeast China. Foodborne Pathogens and Disease. v. 14, n.7, p. 379-385, 2017.

BARRIOS-GARCIA, M.N. \& BALLARI, S.A. Impact of wild boar (Sus scrofa) in its introduced and native range: a review. Biol Invasions, v. 14, n.11, p.2283-2300, 2012.

BURG, J. L. et al. Direct and sensitive detection of a pathogenic protozoan, Toxoplasma gondii, by polymerase chain reaction. Journal of Clinical Microbiology, v. 27, n. 8, p. 1787-92, agos. 1989. ISSN 0095-1137.

DEKSNE, G. \& KIRJUSINA, M. Seroprevalence of Toxoplasma gondii in domestic pigs (Sus scrofa domestica) and wild boars (Sus scrofa) in Latvia. J Parasitol, v. 99, n.1, p. 44-47, 2013.

DUBEY, J. P. Toxoplasmosis. Journal of American Veterinary Medical Association, v. 205, p.1593-1598, 1994.

FORNAZARI, F. et al. Toxoplasma gondii infection in wild boars (Sus scrofa) bred in Brazil. Veterinary Parasitology, v. 164, n. 2-4, p. 333-4, Oct 2009.
HARKER, K. S. et al. Toxoplasma gondii dissemination: a parasite's journey through the infected host. Parasite Immunology, v. 37, n. 3, p. 141-9, Mar 2015.

KANG, S.W. et al. Seroprevalence of Toxoplasma gondii and Trichinella spiralis infections in wild boars (Sus scrofa) in Korea. Parasitol Int. v. 62, n. 6, p.583-585, 2013.

KHALIFA K EL-S et al. Value of PCR for evaluating occurrence of parasitemia in immunocompromised patients with cerebral and extracerebral toxoplasmosis. Journal of Clinical Microbiology, v. 32, n. 11, p. 2813-9, Nov 1994. ISSN 0095-1137.

MASSEI, G. et al. Wild boar populations up, numbers of hunters down? A review of trends and implications for Europe. Pest Management Science, v. 71, n. 4, p. 492-500, Apr 2015. ISSN 1526-4998.

MORGADO, T. O. et. al. Detection of Toxoplasma gondii in a freeranging giant anteater. Ciência Rural, v.47 n. 08, e20161127, 2017. ISSNe 1678-4596.

PEDROSA, F. et al. Current distribution of invasive feral pigs in Brazil: economic impacts and ecological uncertainty. Natureza \& Conservação. 13: 84-87 p. 2015.

ROBERT-GANGNEUX, F.; DARDÉ, M. L. Epidemiology of and diagnostic strategies for toxoplasmosis. Clinical Microbiology Reviews, v. 25, n. 2, p. 264-96, Apr 2012. ISSN 1098-6618.

ROSTAMI, A.; et al. Advances in serological, imaging techniques and molecular diagnosis of Toxoplasma gondii infection. Infection, Jan 2018. ISSN 1439-0973.

ROSTAMI, A et al. The global seroprevalence of Toxoplasma gondii among wild boars: a systematic review and meta-analysis .Veterinary Parasitology, v.244, p.12-20, Jul 2017.

SAMBROOK, J.; RUSSELL, D.W. Molecular cloning: a laboratory manual. 2.ed. New York: CsHL. 2001. 2100p.

SANTOS, L. M. J. D. F. et al. Presence of Toxoplasma gondii infection in wild boar in southern Brazil. Scholars Journal of Agriculture and Veterinary Sciences. 3: 238-241 p. 2016.

SIMBERLOFF, D.Invasive species: what everyone needs to know. 1.ed Oxford: Oxford University Press, 2013. 352p. 